\title{
Gender Budgeting Implementation in Italian Regional Governments: Institutional Behavior for Gender Equality and Women's Empowerment
}

\author{
Carla Del Gesso ${ }^{1}$ \\ ${ }^{1}$ Department of Economics, University of Molise, Campobasso, Italy \\ Correspondence: Carla Del Gesso, Department of Economics, University of Molise, Campobasso, 86100, Italy.
}

Received: November 11, 2019

Accepted: November 26, 2019 Online Published: November 28, 2019

doi:10.5539/ibr.v12n12p110

URL: https://doi.org/10.5539/ibr.v12n12p110

\begin{abstract}
Gender budgeting has great potential to promote the United Nations 2030 Agenda concerning gender equality and women's empowerment. This article shares some reflections on the need to implement and institutionalize gender budgeting at the regional level, both by embedding gender issues into the overall regional government budgetary process and by promoting gender equality disclosures. An empirical insight into the institutional behavior of Italian regional governments is provided. The study seeks to understand how the gender perspective is integrated into the governmental strategy that informs the entire budgetary cycle of Italian regional governments, by performing a thematic analysis of the key regional planning documents. The local promotion of gender budgeting implementation through institutional norms and the practice of gender performance reporting in Italian regional governments are also addressed. The results highlight that although there are differing degrees of commitment to gender equality and women's advancement within the regions, the gender perspective is quite homogeneously integrated into the governmental strategy. Four gendered transversal thematic priorities are identified: the encouragement of women's employment, the promotion of equal gender opportunities, the enhancement of social inclusion, and the combatting of gender-based violence. Furthermore, although nine regional laws establish gender performance reporting, additional reporting tools integrating non-financial information on gender issues are included solely in a small part of the regional government performance reporting systems. A greater organizational and cultural commitment to the institutionalization of the gender budgeting idea is needed in order to allow stakeholders to appreciate the government's value outcomes in all their dimensions, including the gender-related social dimension.
\end{abstract}

Keywords: gender budgeting, gender-responsive policies, gender performance reporting, regional governments, sustainable development goals

\section{Introduction}

\subsection{Background and Rationale for the Study}

Gender budgeting (also called gender responsive budgeting or even gender sensitive budgeting) refers to a systematic approach involving tools, techniques and procedures of the budget cycle to integrate a gender perspective into all stages of the budgetary process, from the planning phase to the final reporting (Downes et al., 2017; Galizzi et al., 2018; Steccolini, 2019). This perspective serves to inform the allocation of government budgets to ensure that spending and revenue allocations address the needs and interests of different social groups, in order to give them equal opportunities and erase gaps and social discrimination linked to sex, ethnicity, class, poverty, location and age (Sodani \& Sharma, 2008). Indeed, by adopting a gender lens, gender budgeting is intended to "achieve more gender equal outcomes as a consequence" (O'Hagan, 2018: p.19). Gender budgeting entails therefore an integrated approach to the budgeting system, which is adopted in order to incorporate (and disclose information about) gender-oriented goals within the strategic plans, programs, and performance reports of an institution. Gender budgeting also represents a tool with which to achieve public sector objectives of improving effectiveness, efficiency, accountability and transparency, thus supporting the principles of good (public) governance and democratic participation (Budlender \& Hewitt, 2002; Corner, 2005; Pollifroni, 2005; 2008; Brody, 2009; Tommaso et al., 2019). Consequently, the implementation of gender-responsive budget statements - that highlight gender priorities and related goals and outcomes - can constitute a pillar of sustainable 
economic development and social progress, given their great potential to reduce persistent gender disparities worldwide (Villagomez, 2004; Rubin \& Bartle, 2005; Pulejo, 2011a; Chakraborty, 2016).

Gender budgeting has been internationally recognized as a key instrument for the promotion of real gender equality and the economic and social empowerment of women, which are very current issues in the field of country sustainable development (Pulejo, 2011a; Addabbo et al., 2015; Koehler, 2016; Leach et al., 2016). Reducing gender-related discrimination, female unemployment, violence against women, persistent gender pay gaps in education and work, and improving family life conditions and so forth, are among the most important priorities of modern society. Indeed, the aim to "achieve gender equality and empower all women and girls" matches specifically one of the Sustainable development goals (SDGs) of the United Nations 2030 Agenda (SDG number five), which commits policymakers, governments, organizations and all stakeholders worldwide to step up their efforts to alleviate inequalities relating to gender (Razavi, 2016). To contribute to this, Europe has also developed a common approach to promoting equality between men and women as a central drive for sustainable economic growth of European countries. In particular, the European Union member states have adopted the EU Gender Action Plan 2016-2020 (GAP II) which aims to promote gender budgeting at national and local levels in partner countries (European Commission, 2018). Accordingly, an institutional approach to the promotion of gender budgeting implementation in order to contribute to the achievement of the goals of United Nations 2030 Agenda is highly topical, and therefore needs more attention both from scholars and practitioners.

However, the interest in gender budgeting from public administration and accounting scholars appears to have been relatively limited, despite growing political, social and economic attention at the macroeconomical level (Marks Rubin \& Bartle, 2005; Siboni et al., 2016; Galizzi et al., 2018). Furthermore, although there has been no lack of countries, both across and beyond Europe, that have introduced gender budgeting into their budget-making (Chakraborty, 2016; Quinn, 2016; Stotsky et al., 2016), gender budgeting appears so far to have been implemented weakly and ineffectively (O'Hagan, 2018). In Europe in particular, a legislative framework, from national and regional governments, has developed across countries to support gender budgeting implementation. Legislation began with the Beijing Platform for Action - formed in 1995 at the Fourth World Conference on Women - which first institutionalized gender budgeting but despite this, the adoption of gender budgeting remains a challenge in different contexts (Quinn, 2017; O’Hagan \& Klatzer, 2018).

In order to achieve the goal of gender equality and women's empowerment, it is essential to advocate gender budgeting at the institutional level to promote and stimulate greater application and thus support effective gender mainstreaming in government strategies, decision-making, programs, processes and reporting. In other words, given the potential gender budgeting has in contributing to the closure of gender gaps, this instrument needs to become institutionalized further in public policy and society in order to encourage successful implementation (Stotsky et al., 2016; Steccolini, 2019). In particular, its establishment within the budgetary cycle and the performance reporting processes can also be made effective through regulations, norms and guidelines. Regional governments worldwide, in virtue of the importance of favoring a sustainable and inclusive development of their territories (Morgan, 2009), have a significant role to play in promoting gender budgeting implementation at a local level to make gender equality and women's empowerment a reality. Thus, in the face of their commitment to tackle gender diversities, regions need to integrate gender-related goals into their internal budgetary processes. In addition, they need to ensure that gender budgeting is established as an officially recognized accounting and accountability practice.

The background outlined above provides the motivation for this research, which seeks to present an empirical insight into the institutional behavior of Italian regional governments with respect to gender budgeting implementation. Specifically, this study aims to explore the degree to which gender budgeting is institutionalized in Italian regions in terms of their concrete commitment to achieving gender equality and women's empowerment, as a goal of the United Nations 2030 Agenda. The following research questions are addressed:

$R Q_{1}$ : How is the gender perspective integrated into the governmental strategy informing the budgetary cycle of Italian regional governments?

$R Q_{2}$ : Is gender budgeting implementation promoted by Italian regions in their territories through institutional norms, in order to encourage local institutions to disclose information on their commitment to gender equality?

$R Q_{3}$ : Is the reporting on gender performance information a common practice in Italian regional governments?

In the case of Italian regions, as bottom-up promoters of gendered initiatives, the interest in gender budgeting appears to be recent with some legislative movement in the last decade. Indeed, although not extensively and 
systematically widespread, gender-responsive budget statements have been implemented in the form of voluntary final gender-responsive reports used to disclose information covering gender issues, related to performance and impacts (Gori et al., 2018; Tommaso et al., 2019). In this study, the current experience of Italian regions in institutionalizing gender budgeting implementation is analyzed by focusing attention firstly on their core regional planning documents, and secondly on their publication of norms and final reports substantiating gender-responsive budgeting. In particular, the fundamental document of regional general planning is the Regional Economic and Financial Document (DEFR, or "Documento di Economia e Finanza Regionale") which was mandatorily introduced in Italian regional governments, starting in 2015, with decree no. 118/2011 on public accounting harmonization (decree no. 118/2011, paragraph 36, subsection 3; and subsequent modifications and additions). The DEFR contains the regional strategic objectives in the various policy areas (economics, social, environmental, etc.) in which the region will intervene during the reference period relating to three years. It is a strategic planning document from which spending and revenue allocations of the regional budget derives, therefore informing the entire regional budgetary cycle.

This article shares some reflections on the need to implement and institutionalize gender budgeting at the regional level, both by embedding gender issues into the overall regional government budgetary process and by promoting gender equality disclosures. It has implications for policymakers, administrators and practitioners in regional and local governments, researchers and all other actors involved in promoting gender budgeting development, both for the budgetary process of governments and the mainstream of scholarly research into public management and accounting. The article continues below with an in-depth look at gender budgeting to support gender equality disclosures through a literature review. The subsequent section 2 better identifies the analyzed target population and materials and explains the methodologies used to answer the research questions. The research results are presented in section 3 . The article concludes by discussing the results in section 4 , which highlights useful elements for further research and some practical recommendations for better gender budgeting implementation.

\subsection{A Review of Previous Literature}

Gender budgeting was first implemented in Australia in the mid-1980s. By the mid-1990s, it had been introduced in numerous countries throughout the world thanks to the impetus of the Beijing Platform for Action of United Nations in 1995, which called for the integration of a gender dimension into budgetary processes (Sharp \& Broomhill, 2002). Today, gender budgeting initiatives have been introduced worldwide both at the national and subnational levels, with varying forms, aims, approaches, scopes and outcomes based on the different political contexts in which they are implemented (Stotsky, 2006; Chakraborty, 2016; Klatzer et al., 2018). Scholarly studies on these initiatives have also increases since the 1990s by highlighting that gender budgeting has been used - "as a disruptive and radical approach to decision-making on public resources and public policy" (O'Hagan, 2018: p.37) - to engender macroeconomic policy aimed at reducing gender inequalities and advancing gender issues, such as tackling violence against women or enhancing women's rights, their status, their access to education or their working conditions, etc. (Budlender \& Hewitt, 2002; Budlender, 2006).

In short, there has been a growth in gender budgeting and several governments around the world have integrated aspects concerning gender issues into budget in order to address gender equality and women's development (Hopper, 2019). Nevertheless, gender budgeting has not been sufficiently considered in the managerial and accounting literature and, as has been highlighted in particular recently, the field of the gender agenda needs greater engagement from accounting scholars (Broadbent, 2016; Siboni et al., 2016).

Gender issues are high up on the agendas of private and public organizations (UN, 2014; UN Women, 2019). This entails the need for an organization to disclose information about their commitment to gender equality, as stakeholder demand for gender performance information increases (Miles, 2011). As Hossain and colleagues argue, providing gender-related disclosures is necessary to meet the increasing call for transparency from and the accountability needs of stakeholders who have a right to be informed about organizational gender practices and matters related to gender equality (Hossain et al., 2016). Moreover, as highlighted by Hopper, a broader vision of accounting and accountability that goes beyond financial value information is required in order to drive organizations towards achieving the compelling global sustainable development goals of the United Nations 2030 Agenda (Hopper, 2019). Gender equality is an important part of this Agenda, which calls for greater social responsibility to ensure well-being and prosperity for the entire society worldwide. In line with this call, various authors have considered gender issues in their studies on corporate social responsibility and stakeholder accountability concerns. Khlif \& Achek (2017) have found however, in their review of the accounting literature dealing with gender issues, that most of these studies have placed emphasis on equal opportunities for women on the board composition and leadership positions of private companies (Grosser \& Moon, 2005; Grosser, 2009, 
Fernandez-Feijoo et al., 2014; Velte, 2017).

Gender balance as a social outcome is one of the multiple dimensions of the value an organization creates, be it public or private. This is because the creation of value includes relevant social aspects, as well as economic, environmental and whole-system aspects of sustainability development and corporate social responsibility (Bebbington \& Dillard, 2008; Henriques, 2013). This is emphasized by the growing literature on sustainability reporting and integrated reporting, which argues that performance reporting systems should include, with a more holistic and comprehensive view of performance, all dimensions of the organizational value creation and thus provide stakeholders with economic, social, environmental, and governance (financial and non-financial) information (Dumay et al., 2016; Adams, 2017; de Villiers \& Maroun, 2017; Manes-Rossi et al., 2018; Del Gesso, 2019). Considering gender diversity matters therefore, has the ability to create an organization's value and consequently, organizational disclosures need to include gender impact information. Gender equality disclosures are also supported by the Global Reporting Initiative (GRI) which, in promoting sustainability reporting practices in private and public organizations internationally, includes gender related indicators in its "GRI Sustainability Reporting Framework" and enacts specific "Social Standards", namely the "GRI 401-Employment" and the "GRI 405-Diversity and Equal Opportunity" Standards that help organizations to report on their social impact related to gender (GRI \& IFC, 2009; GRI website). Despite this, although research on company reporting on gender equality has been developed (e.g., Fernandez-Feijoo et al., 2014) and while sustainability reporting has attracted attention from accounting researchers (e.g., de Villiers \& Maroun, 2017), little research has analyzed organization disclosures on gender issues within the public sector budgetary process.

Some recent experiences of gender budgeting have been analyzed in the Italian public sector. One study focused on gender equality disclosures in the public university context (Galizzi \& Siboni, 2016). Some other studies, in contrast, have dealt with gender budgeting implementation in regional and local governments (Galizzi et al., 2018; Gori et al., 2018; Tommaso et al., 2019). In particular, Gori and colleagues, who explored local authority commitment to gender mainstreaming by examining the strategic planning documents of the regional chief-towns, have pointed out the need to develop a clear framework, with respect to strategies, resources, and performance and impact indicators, to issue effective gender policies (Gori et al., 2018). Furthermore, Galizzi and colleagues analyzed the fully developed practice of gender budgeting in the municipality of Bologna and emphasized how gender budgeting is in line with the principles of public governance processes, such as equity, transparency, participation and accountability (Galizzi et al., 2018). In addition, Tommaso and colleagues examined gender budgeting experiences in Italian local governments by focusing on rules and gender-responsive reports implemented at the regional level, and highlighted the opportunity these reports provide to advance public sector management and public governance processes (Tommaso et al., 2019). This research revealed, however, a sporadic implementation of gender reports and a widespread methodological homogeneity in approaching their adoption. Previous literature has also shown that gender budgeting in Italian regional and local governments is basically designed as an instrument of the reporting stage, while a more holistic budgetary approach to gender issues is required, starting with a definition of the policies that differently determine male and female well-being and leading to the measurement and reporting of their impact (Galizzi, 2010; Addabbo et al., 2011; Pulejo, 2011b).

The gender budgeting potential for a budget reform has already been highlighted (Marks Rubin \& Bartle, 2005); the recent work of Steccolini (2019) has also emphasized the need for the institutionalization of gender budgeting. Therefore, although some gender budgeting experiences at the Italian regional level have been analyzed in previous work, the originality of the present research lies in its investigation of gender budgeting implementation from the standpoint of the need to institutionalize it as an established practice of accounting and accountability processes; this is essential so that gender budgeting is able to deliver long lasting results to realize gender equality and women's rights. In other words, the gender perspective needs to be systematically embedded within the corporate budgetary systems of regional governments (and drive their institutional behavior and commitment) to create gender balance as a social value.

\section{Materials and Methods}

This research is qualitative in nature. It aimed to investigate the institutional commitment of Italian regional governments, with respect to the United Nations 2030 Agenda, to achieving gender equality and women's advancement through gender budgeting implementation.

In Italy, the promotion of gender budgeting appears to have been influenced by a bottom-up movement led by local governments but without coordination, indications for method, tools or funding from central government. Indeed, no specific norms have been enacted by the central government. However, references to gender 
budgeting implementation do appear in two laws. Firstly, decree no. 150/2009, which in imposing the adoption of a performance measurement and management cycle for all Italian public administrations, requires them to report on gender performance in their annual performance reports (decree no. 150/2009, paragraph 10, subsection 1b). Secondly, law no. 196/2009, which in defining the process of the reform and harmonization of public sector accounting, affirms the need for the adoption of a gender budget as a reporting tool to assess the different impacts of budgetary policies on men and women in order to pursue gender equality (law no. 196/2009, paragraph 38-septies; and subsequent modifications and additions).

Therefore, this study focuses on a target population consisting of all 20 Italian regional governments. Regional governments are the largest level of territorial subdivision in Italy, above the provincial and municipal levels. A documentary data collection and analysis were carried out between June and September 2019 in order to answer the three research questions outlined in the Introduction that were addressed sequentially.

Firstly, given the role regions play in promoting gender equality policies in their territories, the study sought to understand how the gender perspective is currently established within their corporate budgetary cycles $\left(R Q_{1}\right)$. To this end, the DEFR for the three-years 2019-21 was gathered from the regions' official websites where it is generally published under the heading "Planning" or "Finances". The decision was made to analyze the DEFR as this mandatory planning document initiates the budgetary process of Italian regional governments, by defining the programming guidelines (or policy objectives) of the government action that guides expenditure allocations both in the annual financial budget (for the year 2019) and in the triennial financial budget (for 2019-2021). Indeed, its narrative structure allows the Regional Executive Council to set out all governmental policies and programs to be implemented over the three-years, as well as the resources needed for the pursuit of regional planning objectives. The three-year planning cycle of the regional budgeting therefore necessarily starts with (and is supported by) the DEFR which constitutes an essential tool for the government's strategic control. In reality, during this study, the Italian regions were in the process of publishing the new DEFR 2020-22 but very few had actually published it, thus the only available document for the entire target population was the DEFR 2019-21 which is currently in force. However, for two regions (Lombardy and Trentino Alto-Adige) the DEFR 2019-21 was not available on the respective websites and consequently, the last available document was analyzed, which related to the period 2017-2019.

The collected DEFR documents were examined by means of a thematic analysis in order to identify the gendered thematic priorities set out by Italian regional governments. Thematic analysis is an independent research approach within the qualitative descriptive methodologies defined as "a method for identifying, analysing and reporting patterns (themes) within data" (Braun \& Clarke, 2006: p.79; Vaismoradi et al, 2013; Nowell et al., 2017). This commonly used method for qualitative research was chosen because it allows themes within a data system which are important to the description of a phenomenon, to be identified (Daly et al., 1997). Thus, it appeared to be particularly appropriate to aid a deeper analysis of the DEFRs to identify all the thematic categories regarding gender-responsive policies and their related disclosures.

In order to build a set of meaningful and established themes, thematic analysis requires a six step process to be carried out. The steps are: familiarization with the data, the generation of initial codes, the search for themes, the reviewing of themes, the definition and naming of themes, and the production of a report (Braun \& Clarke, 2006; Nowell et al., 2017). By following this iterative process, thematic analysis was performed on all 20 DEFRs with the help of the Qualitative Data Analysis software "QDA Miner Lite". The length of the documents was very variable and ranged from 37 to 472 pages. The documentary raw data were therefore explored, and themes (i.e. the gender-related policy priorities set out) were inductively defined and extrapolated. In particular, as a first step, the DEFRs were carefully read so that familiarity with their content could be achieved. Subsequently, a systematic coding for potential themes was done and then, similar codes that were common to the 20 cases were grouped together. In the following step, all the collected codes were sorted to form themes and subthemes. These were then reviewed to check that the data had been well-arranged and to finalize the themes and subthemes; finally, a thematic matrix was defined.

Once the DEFRs were examined through thematic analysis, the study sought to determine whether the Italian regions are promoting gender budgeting implementation in their territories through institutional norms that encourage local provinces and municipalities to disclose information on their commitment to gender equality $\left(R Q_{2}\right)$, such as through regional laws and guidelines. Thus, in order to answer the second research question, an electronic search was conducted within the official regional bulletins (containing laws and regulations) published during the last decade to review gender budgeting-related legislation.

Finally, the study also sought to determine to what extent reporting on gender performance information is a 
common practice in Italian regional governments $\left(R Q_{3}\right)$. In order to address the last research question, an analysis of regional official websites was carried out to search for published non-financial performance reports which disclose information on gender impacts, such as gender-responsive reports, social reports and sustainability reports, in addition to traditional financial reporting statements.

\section{Results}

The results of the study in relation to the three research questions are described below.

Table 1 shows the results relating to $R Q_{1}$ (How is the gender perspective integrated into the governmental strategy informing the budgetary cycle of Italian regional governments?). The thematic analysis conducted on the DEFRs across 20 Italian regional governments made it possible to distinguish four main global themes. These themes were established through the identification of a specific set of subthemes that represent the gender-related policy priorities integrated into the DEFR documents. As detailed in Table 1, the integration of a gender perspective into governmental strategy, which subsequently informs the entire budgetary cycle of Italian regional governments can be expressed through the following four themes: the encouragement of women's employment; the promotion of equal gender opportunities; the enhancement of social inclusion; and the combatting of gender-based violence.

The total number of regions that include the four aforementioned themes within their DEFRs and thus integrate them into their budgetary cycle, is reported in Table 1; the regions that integrate each subtheme are also detailed. As can be seen from this table, the identified themes are all transversal themes, as each theme is recurrent in most Italian regional policies. This would suggest that the experience of promoting gender equality and women's empowerment is homogeneous on the whole. However, by looking at the various subthemes, it can be seen how some regions stand out because they are much more proactive than the others. Indeed, some subthemes are not common, rather they characterize only a part of the regional experience. This is the case of the subtheme "promote gender equality by implementing reporting on gender impact", which is only considered by three regions (Calabria, Emilia-Romagna and Piedmont); in addition, the subtheme "encourage full equity in remuneration" is relatively isolated because only two regions (Friuli-Venezia Giulia and Veneto) have integrated it into their governmental strategy. In contrast, almost all regions (19 regions) have addressed the subtheme "contrast poverty by aiding job placement and income support to vulnerable people" in order to enhance social inclusion of some categories at risk of exclusion, such as the elderly, the disabled, single mothers, and the unemployed who may be experiencing a situation of particular economic fragility. Moreover, several regions (14 regions) have integrated into their DEFRs the political intention to "increase women's access to the labor market through active labor policies, support measures and training"; likewise, there are also 14 regions that have included in their DEFRs the general principle of "promoting a regional policy guaranteeing equal opportunities without discrimination for women and men in work and in social life", as well as their commitment to "support female victims of violence and their children". 
Table 1. Integration of the gender perspective in the governmental strategy of Italian regional governments

\begin{tabular}{|c|c|c|c|}
\hline Themes & Subthemes & In which regions & $\begin{array}{c}\text { Total } \\
\text { number of } \\
\text { regions }\end{array}$ \\
\hline $\begin{array}{l}\text { Encourage } \\
\text { women's } \\
\text { employment }\end{array}$ & $\begin{array}{l}\text { - Improve women's employment } \\
\text { through family policies aimed at } \\
\text { reconciling home and work life; } \\
\text { - Support women's access to career } \\
\text { opportunities, decision-making and } \\
\text { entrepreneurship; } \\
\text { - Encourage full equity in } \\
\text { remuneration. }\end{array}$ & $\begin{array}{l}\text { Abruzzo; Basilicata; Calabria; } \\
\text { Emilia-Romagna; Friuli-Venezia Giulia; } \\
\text { Lazio; Liguria; Lombardy; Marche; } \\
\text { Molise; Piedmont; Puglia; Tuscany; and } \\
\text { Veneto. } \\
\text { Calabria; Emilia-Romagna; Friuli-Venezia } \\
\text { Giulia; Liguria; Molise; Piedmont; Puglia; } \\
\text { Valle d'Aosta; and Veneto. } \\
\text { Emilia-Romagna; Friuli-Venezia Giulia; } \\
\text { Lombardy; Piedmont; and Veneto. } \\
\text { Friuli-Venezia Giulia; and Veneto. }\end{array}$ & 15 regions \\
\hline $\begin{array}{l}\text { Promote equal } \\
\text { gender } \\
\text { opportunities }\end{array}$ & $\begin{array}{l}\text { - Promote gender equality by } \\
\text { implementing reporting on gender } \\
\text { impact; } \\
\text { - Promote a regional policy } \\
\text { guaranteeing equal opportunities } \\
\text { without discrimination for women } \\
\text { and men in work and in social life. }\end{array}$ & $\begin{array}{l}\text { Abruzzo; Basilicata; Calabria; } \\
\text { Emilia-Romagna; Friuli-Venezia Giulia; } \\
\text { Lazio; Lombardy; Marche; Piedmont; } \\
\text { Puglia; Sicily; Tuscany; Valle d'Aosta; and } \\
\text { Veneto. }\end{array}$ & 14 regions \\
\hline $\begin{array}{l}\text { Enhance social } \\
\text { inclusion }\end{array}$ & $\begin{array}{l}\text { - Improve women's well-being through } \\
\text { educational projects, gender-specific } \\
\text { care, or sport; } \\
\text { - Contrast poverty by aiding job } \\
\text { placement and income support to } \\
\text { vulnerable people; }\end{array}$ & $\begin{array}{l}\text { Abruzzo; Basilicata; Emilia-Romagna; } \\
\text { Friuli-Venezia Giulia; Liguria, and } \\
\text { Lombardy. } \\
\text { Abruzzo; Basilicata; Calabria; Campania; } \\
\text { Emilia-Romagna; Friuli-Venezia Giulia; } \\
\text { Lazio; Liguria; Lombardy; Marche; } \\
\text { Molise; Piedmont; Puglia; Sardinia; Sicily; } \\
\text { Tuscany; Umbria; Valle d'Aosta; and } \\
\text { Veneto. } \\
\text { Calabria; Emilia-Romagna; Friuli-Venezia } \\
\text { Giulia; Lazio; Lombardy; Marche; Molise; } \\
\text { Piedmont; and Puglia. }\end{array}$ & 19 regions \\
\hline $\begin{array}{l}\text { Contrast } \\
\text { gender-based } \\
\text { violence }\end{array}$ & $\begin{array}{l}\text { - Promote territorial networks, } \\
\text { partnerships and information } \\
\text { campaigns to raise awareness of the } \\
\text { gender violence issue; } \\
\text { - Support anti-violence centers and } \\
\text { shelters. }\end{array}$ & $\begin{array}{l}\text { Abruzzo; Basilicata; Calabria; } \\
\text { Emilia-Romagna; Friuli-Venezia Giulia; } \\
\text { Lazio; Liguria; Lombardy; Marche; } \\
\text { Piedmont; Puglia; Sicily; Tuscany; and } \\
\text { Veneto. } \\
\text { Abruzzo; Emilia-Romagna; Lombardy; } \\
\text { Marche; Piedmont; Puglia; Tuscany; and } \\
\text { Veneto. } \\
\text { Abruzzo; Calabria; Emilia-Romagna; } \\
\text { Lombardy; Marche; Piedmont; Puglia; } \\
\text { Tuscany; and Veneto. }\end{array}$ & 14 regions \\
\hline
\end{tabular}

Source: data analyzed from the results of the thematic analysis of the DEFRs 2019-21 of Italian regional governments.

Table 2 shows the results in response to $R Q_{2}$ (Is gender budgeting implementation promoted by Italian regions in their territories through institutional norms, in order to encourage local institutions to disclose information on their commitment to gender equality?). Nine regions out of twenty have enacted a law promoting gender budgeting establishment from 2007 to date. The nine regional laws are listed in chronological order in Table 2, which reports what they state about gender budgeting implementation at the local level. As is detailed in this table, eight laws are specifically concerned with gender issues, while one law (in the case of Calabria) is a general legal provision in which only the government's adoption of gender budgeting is promoted. Therefore, eight regions promote gender budgeting implementation both in their budgetary process and in those of the local authorities in their territories; however, only two of these regions (Emilia-Romagna and Piedmont) also provide guidelines for their local authorities. The regional laws establishing gender budgeting are quite homogeneous in their objectives and scope. Although some laws also establish specific training and updating activities to instruct 
staff on how to apply gender budgeting and prepare gender-responsive reports, the requirement of other paragraphs are somewhat identical.

Table 2. The promotion of gender budgeting implementation in Italian regional laws

\begin{tabular}{|c|c|c|c|c|}
\hline \multirow[b]{2}{*}{ Region } & \multirow[b]{2}{*}{ Regulatory law } & \multicolumn{2}{|c|}{ The establishment of gender budgeting at the local level } & \multirow{2}{*}{$\begin{array}{l}\text { Were } \\
\text { guidelines } \\
\text { provided? }\end{array}$} \\
\hline & & Establishment of government adoption & $\begin{array}{c}\text { Promotion among the regional } \\
\text { local authorities }\end{array}$ & \\
\hline Puglia & $\begin{array}{l}\text { Law no. } 7 \text { from } 21 \\
\text { March } 2007 \text { : } \\
\text { "Rules for gender } \\
\text { policies and } \\
\text { work-life balance } \\
\text { services". }\end{array}$ & $\begin{array}{l}\text { "The Region in the report that } \\
\text { accompanies both the forecasting } \\
\text { budget and the final financial reporting } \\
\text { statements includes the gender budget } \\
\text { as a tool for monitoring and assessing } \\
\text { the impact of regional policies on men } \\
\text { and women". (Paragraph 19, } \\
\text { subsection 1). }\end{array}$ & $\begin{array}{l}\text { "The Region promotes the } \\
\text { dissemination of gender budget } \\
\text { among the Apulian local } \\
\text { authorities through initiatives, } \\
\text { awareness raising and } \\
\text { information from the Regional } \\
\text { Resource Center for Women". } \\
\text { (Paragraph 19, subsection 3). }\end{array}$ & No \\
\hline Calabria & $\begin{array}{l}\text { Law no. } 15 \text { from } 13 \\
\text { June } 2008 \text { : } \\
\text { "General measures } \\
\text { of a legal and } \\
\text { financial type" }\end{array}$ & $\begin{array}{l}\text { "[...] to improve citizen participation } \\
\text { and comprehensibility and } \\
\text { transparency of the budget, the } \\
\text { Regional Executive Council prepares } \\
\text { in addition to the social report, a } \\
\text { gender-responsive report". (Paragraph } \\
\text { 12, subsection 1). }\end{array}$ & 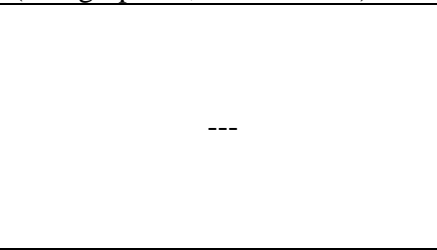 & No \\
\hline Liguria & $\begin{array}{l}\text { Law no. } 26 \text { from } 1 \\
\text { August } 2008: \\
\text { "Integration of } \\
\text { gender equal } \\
\text { opportunities } \\
\text { policies in the } \\
\text { Liguria Region". }\end{array}$ & $\begin{array}{l}\text { "The Region adopts gender budgeting } \\
\text { as a social reporting tool that allows } \\
\text { the integration of the gender } \\
\text { perspective into economic planning } \\
\text { documents in which public policies are } \\
\text { defined and summarized". (Paragraph } \\
8 \text {, subsection 1). }\end{array}$ & $\begin{array}{l}\text { "The Region promotes the } \\
\text { dissemination of the gender } \\
\text { budgeting tool among all local } \\
\text { authorities. [...] With a specific } \\
\text { act, the Regional Executive } \\
\text { Council dictates the guidelines } \\
\text { and identifies the methodologies } \\
\text { for the design and } \\
\text { implementation of the gender } \\
\text { budget". (Paragraph 9, } \\
\text { subsections } 1 \text { and } 3 \text { ). }\end{array}$ & No \\
\hline Piedmont & $\begin{array}{l}\text { Law no. } 8 \text { from } 18 \\
\text { March 2009: } \\
\text { "Integration of } \\
\text { gender equal } \\
\text { opportunities } \\
\text { policies in the } \\
\text { Piedmont Region } \\
\text { and provisions for } \\
\text { the establishment of } \\
\text { gender budgets". }\end{array}$ & $\begin{array}{l}\text { "For the purposes of this law, gender } \\
\text { budgeting consists of assessing the } \\
\text { impact of budgetary policies on gender } \\
\text { by identifying gender-sensitive areas in } \\
\text { order to promote equality of } \\
\text { opportunity between men and } \\
\text { women". (Paragraph 3, subsection 1). }\end{array}$ & $\begin{array}{l}\text { "The Regional Executive } \\
\text { Council [...] prepares a vade } \\
\text { mecum relating to the guidelines } \\
\text { for the implementation of gender } \\
\text { budgets in order to promote and } \\
\text { solicit their adoption in local } \\
\text { authorities". (Paragraph 5, } \\
\text { subsection 2). }\end{array}$ & Yes \\
\hline Tuscany & $\begin{array}{l}\text { Law no. } 16 \text { from } 2 \\
\text { April 2009: } \\
\text { "Gender } \\
\text { citizenship". }\end{array}$ & $\begin{array}{l}\text { "The gender budget, drawn up by the } \\
\text { Regional Executive Council, is a tool } \\
\text { for monitoring and evaluating regional } \\
\text { policies on equal opportunities in the } \\
\text { context of the overall legislative } \\
\text { evaluation of regional public policies". } \\
\text { (Paragraph 13, subsection } 1 \text { ). }\end{array}$ & $\begin{array}{l}\text { "The Region also promotes the } \\
\text { dissemination of the gender } \\
\text { budget among local authorities } \\
\text { for the purpose of guiding } \\
\text { actions for work-life balance". } \\
\text { (Paragraph 13, subsection 3). }\end{array}$ & No \\
\hline $\begin{array}{l}\text { Friuli- } \\
\text { Venezia } \\
\text { Giulia }\end{array}$ & $\begin{array}{l}\text { Law no. } 20 \text { from } 16 \\
\text { November } 2010 \text { : } \\
\text { "Measures for the } \\
\text { promotion of social } \\
\text { reporting in the } \\
\text { Administrations of } \\
\text { Friuli-Venezia } \\
\text { Giulia". }\end{array}$ & $\begin{array}{l}\text { "The present law pursues the objective } \\
\text { of developing the ability of [...] regions } \\
\text { and local authorities to implement } \\
\text { effective social reporting processes, } \\
\text { through documents such as the annual } \\
\text { social report, the mandate social } \\
\text { report, the environmental report, the } \\
\text { gender-responsive report [...] and other } \\
\text { social reporting documents". } \\
\text { (Paragraph 1). }\end{array}$ & $\begin{array}{l}\text { "The present law pursues the } \\
\text { objective of developing the } \\
\text { ability of [...] regions and local } \\
\text { authorities to implement } \\
\text { effective social reporting } \\
\text { processes.... (Idem as paragraph } \\
\text { 1). }\end{array}$ & No \\
\hline Marche & $\begin{array}{l}\text { Law no. } 23 \text { from } 23 \\
\text { July 2012: } \\
\text { "Integration of } \\
\text { gender equal } \\
\text { opportunities }\end{array}$ & $\begin{array}{l}\text { "The gender budget, drawn up by the } \\
\text { Regional Executive Council, is a tool } \\
\text { for monitoring and evaluating regional } \\
\text { policies on equal opportunities, as part } \\
\text { of the overall assessment of regional }\end{array}$ & $\begin{array}{l}\text { "The Region also promotes the } \\
\text { dissemination of the gender } \\
\text { budget among local authorities } \\
\text { for the purpose of guiding action } \\
\text { for work-life balance". }\end{array}$ & No \\
\hline
\end{tabular}




\begin{tabular}{|c|c|c|c|c|}
\hline & $\begin{array}{l}\text { policies in the } \\
\text { Region". }\end{array}$ & $\begin{array}{l}\text { public policies". (Paragraph 7, } \\
\text { subsection 1). }\end{array}$ & (Paragraph 7, subsection 3). & \\
\hline $\begin{array}{l}\text { Emilia- } \\
\text { Romagna }\end{array}$ & $\begin{array}{l}\text { Law no. } 6 \text { from } 27 \\
\text { June 2014: } \\
\text { "Framework law } \\
\text { for equality and } \\
\text { against gender } \\
\text { discrimination". }\end{array}$ & $\begin{array}{l}\text { "The gender budget, as social reporting } \\
\text { of the integration of a gender } \\
\text { perspective in the economic planning } \\
\text { of public policies [...] is prepared } \\
\text { annually by the Regional Executive } \\
\text { Council, coinciding with the } \\
\text { presentation of the annual report on the } \\
\text { basis of the guidelines and with the } \\
\text { methods established by it, and involves } \\
\text { the adoption of a gender impact } \\
\text { assessment of budgetary policies". } \\
\text { (Paragraph 36, subsection } 1 \text { ). }\end{array}$ & $\begin{array}{l}\text { "The Region also promotes the } \\
\text { dissemination of the gender } \\
\text { budget among local authorities in } \\
\text { order to promote positive action } \\
\text { for reconciling life and work } \\
\text { times and sharing care } \\
\text { responsibilities". (Paragraph } 36 \text {, } \\
\text { subsection } 3 \text { ). }\end{array}$ & Yes \\
\hline Umbria & $\begin{array}{l}\text { Law no. } 14 \text { from } 25 \\
\text { November } 2016 \text { : } \\
\text { "Rules for gender } \\
\text { policies and for a } \\
\text { new civilization of } \\
\text { relations between } \\
\text { women and men". }\end{array}$ & $\begin{array}{l}\text { "The gender budget, approved by the } \\
\text { Regional Executive Council, is a tool } \\
\text { for monitoring and assessing the } \\
\text { impact of regional policies on men and } \\
\text { women". (Paragraph 47, subsection 1). }\end{array}$ & $\begin{array}{l}\text { "The Region promotes its } \\
\text { dissemination among local } \\
\text { authorities by sharing } \\
\text { methodologies, support, and } \\
\text { implementation support". } \\
\text { (Paragraph 47, subsection } 1 \text { ). }\end{array}$ & No \\
\hline
\end{tabular}

Source: elaboration from the review of the regulatory laws on gender budgeting published in the official regional bulletins.

Table 3 shows the results in relation to $R Q_{3}$ (Is the reporting on gender performance information a common practice in Italian regional governments?). In particular, it shows the behavior of Italian regions in respect to the dissemination of gender-responsive and social reports that disclose gender performance information in terms of the impacts of the implemented policies on men and women. As can be seen, regional government reporting of this information in addition to their traditional financial reporting is sporadic. Indeed, additional reporting tools that integrate non-financial information about gender issues are included solely in a small part of the Italian regional government performance reporting systems, although several regions have integrated some disclosures into their annual performance reports to comply with the provisions of national decree no. 150/2009. Specifically, only three regions are now reporting on gender performance or have recently reported on it with specific gender-responsive reports (Emilia-Romagna, Tuscany and Piedmont), whereas some regions have only published a single edition of such a report, more than a decade ago (such as the Marche and the Valle d'Aosta). A positive note is that gender budgeting projects are on the agenda in many regions, meaning that the implementation of performance reporting on gender issues is scheduled for the near future.

Table 3. Regional government reporting on gender performance information

\begin{tabular}{|c|c|c|}
\hline Region & $\begin{array}{l}\text { Additional reporting tools disclosing } \\
\text { non-financial information on gender } \\
\text { performance }\end{array}$ & Projects of implementing gender performance reporting \\
\hline Abruzzo & $\begin{array}{l}\text { Some disclosure is integrated into the } \\
\text { Annual Performance Report. }\end{array}$ & $\begin{array}{l}\text { Resolution no. } 380 \text { of the Regional Executive Council from } \\
1 \text { July } 2019 \text { which plans to prepare a Gender-Responsive } \\
\text { Report by } 2021 \text {. }\end{array}$ \\
\hline Basilicata & $\begin{array}{l}\text { Some disclosure is integrated into the } \\
\text { Annual Performance Report. }\end{array}$ & --- \\
\hline Calabria & $\begin{array}{l}\text { Some disclosure is integrated into the } \\
\text { Annual Performance Report. }\end{array}$ & $\begin{array}{l}\text { A regional communication from } 27 \text { June } 2016 \text { describes an } \\
\text { ongoing project concerning the drafting of the first social } \\
\text { and gender report of the Region. }\end{array}$ \\
\hline Campania & --- & $\begin{array}{l}\text { The regional Council presented a law proposal from } 17 \\
\text { March } 2017 \text { on the implementation of gender budgeting. }\end{array}$ \\
\hline $\begin{array}{l}\text { Emilia- } \\
\text { Romagna }\end{array}$ & $\begin{array}{l}\text { Gender-Responsive Report 2015; } \\
\text { Gender-Responsive Report 2016. Some } \\
\text { disclosure is also integrated into the Annual } \\
\text { Performance Report. }\end{array}$ & $\begin{array}{llll} & \\
\end{array}$ \\
\hline $\begin{array}{l}\text { Friuli-Venezia } \\
\text { Giulia }\end{array}$ & $\begin{array}{l}\text { Some disclosure is integrated into the } \\
\text { Annual Performance Report. }\end{array}$ & 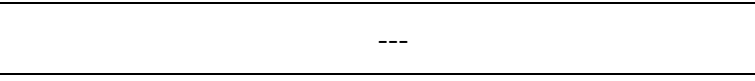 \\
\hline Lazio & $\begin{array}{l}\text { Some disclosure is integrated into the } \\
\text { Annual Performance Report. }\end{array}$ & $\begin{array}{l}\text { In an informative note on the regional website, the region } \\
\text { declares that it will establish a Control room for the } \\
\text { experiment of a Gender-Responsive Report starting from }\end{array}$ \\
\hline
\end{tabular}




\begin{tabular}{|c|c|c|}
\hline & & 2019. \\
\hline Liguria & $\begin{array}{l}\text { Some disclosure is integrated into the } \\
\text { Annual Performance Report. }\end{array}$ & --- \\
\hline Lombardy & 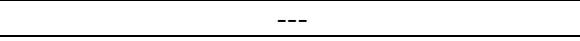 & --- \\
\hline Marche & $\begin{array}{l}\text { Gender-Responsive Report 2005. Some } \\
\text { disclosure is now integrated into the Annual } \\
\text { Performance Report. }\end{array}$ & --- \\
\hline Molise & --- & --- \\
\hline Piedmont & $\begin{array}{l}\text { Gender-Responsive Report 2006; } \\
\text { Gender-Responsive Report 2007/2008; } \\
\text { Gender-Responsive Report 2009/2010; } \\
\text { Simplified (social) Report for Citizens 2016. }\end{array}$ & --- \\
\hline Puglia & $\begin{array}{l}\text { Proof of a gender-responsive report } \\
2010 / 2011 \text { is available. Some disclosure is } \\
\text { integrated into the Annual Performance } \\
\text { Report. }\end{array}$ & $\begin{array}{l}\text { The Resolution no. } 1798 \text { of the Regional Executive Council } \\
\text { from } 7 \text { October } 2019 \text { planned the preparation of a social and } \\
\text { gender report. }\end{array}$ \\
\hline Sardinia & --- & --- \\
\hline Sicily & $\begin{array}{l}\text { Some disclosure is integrated into the } \\
\text { Annual Performance Report. }\end{array}$ & --- \\
\hline $\begin{array}{l}\text { Trentino Alto } \\
\text { Adige }\end{array}$ & e & --- \\
\hline Tuscany & $\begin{array}{l}\text { Gender-Responsive Report 2012/2013; } \\
\text { Gender-Responsive Report 2010/2014; } \\
\text { Social Report 2010; Social Report 2011; } \\
\text { Social Report 2010-2014. }\end{array}$ & --- \\
\hline Umbria & --- & --- \\
\hline Valle d'Aosta & Gender-Responsive Report 2004. & - -- $^{2}$ \\
\hline Veneto & $\begin{array}{l}\text { Several annual editions of the social report } \\
\text { from } 2004 \text { to } 2010 \text {, some of which include } \\
\text { gender performance information. }\end{array}$ & $\begin{array}{l}\text { The Resolution no. } 1701 \text { of the Regional Executive Council } \\
\text { from } 24 \text { October } 2017 \text { refers to the adoption of gender } \\
\text { budgeting as a planning and auditing tool. }\end{array}$ \\
\hline
\end{tabular}

Source: elaboration from the results of an analysis of regional official websites.

\section{Discussion and Conclusion}

This research was based on the view that regions can play a decisive role in establishing gender budgeting within governmental accounting and accountability systems in virtue of their institutional commitment to the United Nations 2030 Agenda goal concerning gender equality and women's empowerment in local communities. The institutional behavior of Italian regional governments was analyzed in respect to the integration of the gender perspective in the regional budgetary strategy, the local promotion of gender budgeting implementation and performance reporting.

In response to the first research question, the results described in the previous section highlight that although there are differing degrees of commitment to gender equality and the advancement of women, the gender perspective is quite homogeneously integrated into the governmental strategy that informs the budgetary cycle of Italian regional governments. Gender-responsive policies are therefore adopted and they may be traced back to four main themes or areas where regional governments make interventions: the encouragement of women's employment, the promotion of equal gender opportunities, the enhancement of social inclusion, and the combatting of gender-based violence.

In particular, better access to the labor market for women is considered a priority and supported by most of the regional policies that are also concerned with tackling women's unemployment through gender training. It has been confirmed that the latter has received much attention from Italian local policies that aim to increase women's empowerment (Gori et al., 2018). In some regions, social and labor policies also aim to help balance women's family and work roles and hours, or to support their career opportunities through entrepreneurship and self-employment in order to reach a greater economic and social equity for the community. Ensuring equal opportunities for all, with no discrimination at work and in social life, as well as tackling poverty and violence against women, appear to be policies informing the budgetary cycle of almost all Italian regional governments. However, only three regions (Calabria, Emilia-Romagna, and Piedmont) include among their governmental policies the promotion of gender performance reporting to help equal gender opportunities. These regions have also enacted a law to promote gender budgeting implementation. In addition, two of these regions (Emilia-Romagna and Piedmont) are the only regions that have issued regional guidelines to help region local authorities implement gender budgeting. These two regions are also those whose performance reporting systems 
include reporting tools (such as gender-responsive reports), which disclose gender performance information that is essential to enable the impact evaluation of the policies to be carried out.

In response to the second research question, the results corroborate the fact that a legislative movement has occurred during the last decade, which has concerned Italian regional governments (Pulejo, 2011a; Tommaso et al., 2019). To date, nine regions have enacted a regional law establishing gender budgeting implementation in their territories. Eight laws promote it, both in the regional government's budgetary process and in that of the region's local authorities. However, the regional laws address gender budgeting with a mostly homogeneous approach and remain limited in scope and objectives (Tommaso et al., 2019).

Furthermore, some laws have also envisaged the enactment of regional guidelines in order to help gender budgeting establishment in the territorial local authorities; however, as already highlighted, only two regions have actually issued such guidelines. This may be due to the change in the elective decision-making bodies which, based on their governmental political orientation, give different levels of salience to gender issues during their electoral mandate. The duration of the elected bodies' mandate therefore can critically affect the regional administration and limit the long-lasting effects of some policies, such as promoting gender budgeting. Nonetheless, gender budgeting implementation cannot be an idea that belongs to one political alignment but needs to be seen as an accounting matter to be established within governmental practice relating to accounting and accountability. Indeed, accounting cannot remain blinkered when considering sustainable development issues such as gender equality and women's empowerment (Hopper, 2019). In addition, providing non-financial information on gender equality commitment is becoming relevant to meet the growing demands from stakeholders for efficiency, equity, transparency and accountability (Miles, 2011; Hossain et al., 2016). This is also in line with public governance principles (Galizzi et al., 2018), according to which the performance disclosure fulfills the governmental need to address value creation for all of society, in all its many dimensions (Bebbington \& Dillard, 2008; Dumay et al., 2016).

From the Italian regional laws, it has emerged that gender budgeting is mainly conceived as a social reporting tool with which to disclose the gender impact assessment of budgetary policies that have been implemented (Galizzi, 2010; Addabbo et al., 2011; Pulejo, 2011b). These laws, therefore, aim to institutionalize a performance reporting tool promoting government disclosures on gender equality evaluation. Inconsistently, however, most regions that have established gender budgeting implementation through the adoption of a gender-responsive report appear not to have adopted such a tool.

The reporting by Italian regional governments on gender performance information was explored in response to the third research question. The results showed that reporting on gender performance issues is not a common practice, although some gender-related information is integrated into the annual performance reports of several regional governments. More precisely, a small number of Italian regional governments are implementing (or have implemented in the past) - in the final stage of their budgetary process - additional reporting tools that disclose non-financial information on gender issues, such as gender-responsive reports and social reports. Reporting on gender issues, therefore, remains isolated; however, in some regions, gender budgeting implementation is an ongoing project, which should allow for an increase in gender performance reporting in the near future. This increase will also depend on the political governance of the regions. However, the fact that some recent regional government institutional resolutions provide for the forthcoming adoption of gender budgeting suggests that gender performance reporting needs more attention not only politically but also academically; indeed, it needs to be studied more in the context of performance measurement and reporting systems and public sector sustainability reporting.

The empirical glance of the Italian regional government experience this study has provided highlights how there is a need for a greater organizational and cultural commitment to the institutionalization and spread of the gender budgeting idea. Formally promoting gender budgeting through laws is not enough; regions also need to provide concrete examples by integrating gender-related information into their performance reporting systems in order to allow stakeholders to appreciate the government's value outcomes in all their dimensions, including the gender-related social dimension.

Gender performance reporting needs to become part of managerial culture and accounting practice as a generally accepted and recognized way of creating value. This is a challenge that, as the experience of Italian regional governments shows, has just begun. Greater political efforts from the various actors at the local level, as well as at the central level, are therefore required, given the strong global attention given to the United Nations 2030 Agenda concerning gender equality and women's empowerment. On the other hand, gender budgeting entails the integration of the gender perspective into the budgetary process and hence, involves the embedding of the gender 
perspective into governmental policies that can be implemented and their results measured and reported. Thus, performance reporting systems cannot be neutral, they must become involved in order to enhance both the government's accountability and strategic control.

Finally, it is recommended that regional governments place a greater focus on gender policies in their strategic plans informing the governmental budgetary cycle; this is the first step in gender budgeting implementation which also implies the adoption of performance measurement and reporting tools that will allow the outcomes of these policies to be assessed and disclosed to stakeholders. In particular, some gender policies need more strategic integration for a real government contribution to achieving the goal of gender equality and women's empowerment. These policies could include: parental leave policies aimed at balancing home and work life; supporting women's access to career opportunities, decision-making and entrepreneurship; tackling inequity in the workplace such as by encouraging full equity in remuneration; improving women's well-being such as by supporting gender-specific care, education and social projects; promoting social inclusion through targeted social measures and services such as by developing social housing; and encouraging territorial networks, partnerships and information campaigns to raise awareness of the gender violence issue. In other words, a greater integration of the gender perspective in governmental policies involves adopting this perspective in all strategic areas of intervention: labor policies, family policies, health policies and welfare and social policies. More gender-responsive regional policies would ultimately help to promote positive behavior. This will contribute to using public resources with increasing equity for citizens, thus strengthening gender equality and the role of women in the family, at work and in society.

\section{References}

Adams, C. (2017). Understanding integrated reporting: the concise guide to integrated thinking and the future of corporate reporting. Abingdon, UK: Routledge. https://doi.org/10.4324/9781351275002

Addabbo, T., Badalassi, G., Corrado, F., \& Picchio, A. (2011). A social-reproduction and well-being approach to gender budgets: experiments at local government level in Italy. In E. Addis, P. de Villota, F. Degavre, \& J. Eriksen (Eds.), Gender and Well-Being. The Role of Institutions (pp. 105-124). UK: MPG Books Group.

Addabbo, T., Gunluk-Senesen, G., \& O'Hagan, A. (2015). Gender budgeting: Insights from current methodologies and experiences in Europe. Politica Economica, 31(2), 125-134. https://doi.org/10.1429/80929

Bebbington, J., \& Dillard, J. (2008). Social sustainability: an organizational-level analysis. In J. Dillard, V. Dujon, \& M. C. (Eds.), King Understanding the social dimension of sustainability (pp. 173-189). New York: Routledge. https://doi.org/10.4324/9780203892978

Braun, V., \& Clarke, V. (2006). Using thematic analysis in psychology. Qualitative Research in Psychology, 3(2), 77-101. https://doi.org/10.1191/1478088706qp063oa

Broadbent, J. (2016). A gender agenda. Meditari Accountancy Research, 24(2), 169-181. https://doi.org/10.1108/MEDAR-07-2015-0046

Brody, A. (2009). Gender and governance: Overview Report. Brighton, UK: Institute of Development Studies.

Budlender, D. (2006). Expectations versus realities in gender-responsive budget initiatives. In S. Razavi, \& S. Hassim (Eds.), Gender and Social Policy in a Global Context: Uncovering the Gendered Structure of 'the Social' (pp. 322-339). London, UK: Palgrave Macmillan. https://doi.org/10.1108/MEDAR-07-2015-0046

Budlender, D., \& Hewitt, G. (2002). Gender budgets make more cents: country studies and good practice. London, UK: The Commonwealth Secretariat.

Chakraborty, L. (2016). Asia: A survey of gender budgeting efforts. Washington, DC: International Monetary Fund. https://doi.org/10.5089/9781475519914.001

Corner, L. (2005). Gender-sensitive and pro-poor indicators of good governance. Oslo, Norway: Oslo Governance Centre, UNDP (United Nations Development Programme).

Daly, J., Kellehear, A., \& Gliksman, M. (1997). The public health researcher: A methodological guide. Melbourne, Australia: Oxford University Press.

de Villiers, C., \& Maroun, W. (Eds.) (2017). Sustainability accounting and integrated reporting. Abingdon, UK: Routledge. https://doi.org/10.4324/9781315108032

Del Gesso, C. (2019). Involving stakeholders in university hospital performance reporting: The state of the art in Italy. African Journal of Business Management, 13(11), 353-372. https://doi.org/10.5897/AJBM2019.8799 
Downes, R., Von Trapp, L., \& Nicol, S. (2017). Gender budgeting in OECD countries. OECD Journal on Budgeting, 16(3), 71-107. https://doi.org/10.1787/budget-16-5jfq80dq1zbn

Dumay, J., Bernardi, C., Guthrie, J., \& Demartini, P. (2016). Integrated reporting: a structured literature review. Accounting Forum, 40(3), 166-185. https://doi.org/10.1016/j.accfor.2016.06.001

European Commission. (2018). Annual Implementation Report 2017. EU Gender Action Plan II Gender Equality and Women's Empowerment: Transforming the Lives of Girls and Women through EU External Relations 2016-2020. Retrieved from https://ec.europa.eu/europeaid/sites/devco/files/eu_gap_2017.pdf

Fernandez-Feijoo, B., Romero, S., \& Ruiz-Blanco, S. (2014). Women on boards: do they affect sustainability reporting? Corporate Social Responsibility and Environmental Management, 21(6), 351-364. https://doi.org/10.1002/csr.1329

Galizzi, G., \& Siboni, B. (2016). Positive action plans in Italian universities: Does gender really matter? Meditari Accountancy Research, 24(2), 246-268. https://doi.org/10.1108/MEDAR-09-2015-0062

Galizzi, G. (2010). The Formulation of Gender Sensitive Budgets: Integrating Gender into the Balanced Scorecard. Economia Aziendale Online, 3, 335-343.

Galizzi, G., Bassani, G., \& Cattaneo, C. (2018). Adoption of Gender-Responsive Budgeting (GRB) by an Italian Municipality. Administrative Sciences, 8(4), 68. https://doi.org/10.3390/admsci8040068

Global Reporting Initiative (GRI). \& International Finance Corporation (IFC) (2009). Embedding Gender in Sustainability Reporting - A Practitioner's Guide. Retrieved from https://www.globalreporting.org/resourcelibrary/Embedding-Gender-In-Sustainability-Reporting.pdf

Gori, E., Romolini, A., \& Fissi, S. (2018). Local Authorities' Policies for Disseminating Gender Equality. Evidence from Italy. Transylvanian Review of Administrative Sciences, 14(53), 38-53. https://doi.org/10.24193/tras.53E.3

Grosser, K. (2009). Corporate social responsibility and gender equality: women as stakeholders and the European Union sustainability strategy. Business Ethics: A European Review, 18(3), 290-307. https://doi.org/10.1111/j.1467-8608.2009.01564.x

Grosser, K., \& Moon, J. (2005). Gender mainstreaming and corporate social responsibility: Reporting workplace issues. Journal of Business Ethics, 62(4), 327-340. https://doi.org/10.1007/s10551-005-5334-3

Henriques, A. (2013). CSR, sustainability and the triple bottom line. In A. Henriques, \& J. Richardson (Eds.), The triple bottom line: Does it all add up? (pp. 26-33). London, UK: Routledge. https://doi.org/10.4324/9781849773348

Hopper, T. (2019). Stop accounting myopia: - Think globally: a polemic. Journal of Accounting \& Organizational Change, 15(1), 87-99. https://doi.org/10.1108/JAOC-12-2017-0115

Hossain, D. M., Ahmad, N. N. N., \& Siraj, S. A. (2016). Marxist feminist perspective of corporate gender disclosures. Asian Journal of Accounting and Governance, 7, 11-24. https://doi.org/10.17576/AJAG-2016-07-02

Khlif, H., \& Achek, I. (2017). Gender in accounting research: a review. Managerial Auditing Journal, 32(6), 627-655. https://doi.org/10.1108/MAJ-02-2016-1319

Klatzer, E., Addabbo, T., Alarcon-García, G., \& O’Hagan, A. (2018). Developments in Practice: Methodologies and Approaches to Gender Budgeting. In A. O'Hagan, \& E. Klatzer (Eds.), Gender Budgeting in Europe: Developments and challenges (pp. 109-133). Cham, Switzerland: Palgrave Macmillan. https://doi.org/10.1007/978-3-319-64891-0_6

Koehler, G. (2016). Tapping the Sustainable Development Goals for progressive gender equity and equality policy? Gender \& Development, 24(1), 53-68. https://doi.org/10.1080/13552074.2016.1142217

Leach, M., Mehta, L., \& Prabhakaran, P. (2016). Gender equality and sustainable development: a pathways approach. Discussion paper for the World Survey on the Role of Women in Development 2014. New York: UN Women. https://doi.org/10.18356/2c5436ac-en

Manes-Rossi, F., Tiron-Tudor, A., Nicolò, G., \& Zanellato, G. (2018). Ensuring more sustainable reporting in Europe using non-financial disclosure-De facto and de jure evidence. Sustainability, 10(4), 1162. https://doi.org/10.3390/su10041162

Marks Rubin, M., \& Bartle, J. R. (2005). Integrating gender into government budgets: A new perspective. Public 
Administration Review, 65(3), 259-272. https://doi.org/10.1111/j.1540-6210.2005.00452.x

Miles, K. (2011). Embedding gender in sustainability reports. Sustainability Accounting, Management and Policy Journal, 2(1), 139-146. https://doi.org/10.1108/20408021111162164

Morgan, A. D. (2009). Learning communities, cities and regions for sustainable development and global citizenship. Local Environment, 14(5), 443-459. https://doi.org/10.1080/13549830902903773

Nowell, L. S., Norris, J. M., White, D. E., \& Moules, N. J. (2017). Thematic analysis: Striving to meet the trustworthiness criteria. International Journal of Qualitative Methods, 16(1), 1-13. https://doi.org/10.1177/1609406917733847

O’Hagan, A. (2018). Conceptual and Institutional Origins of Gender Budgeting. In A. O’Hagan, \& E. Klatzer (Eds.), Gender Budgeting in Europe: Developments and challenges (pp. 19-42). Cham, Switzerland: Palgrave Macmillan. https://doi.org/10.1007/978-3-319-64891-0_2

O’Hagan, A., \& Klatzer, E. (Eds.). (2018). Gender budgeting in Europe: Developments and challenges. Cham, Switzerland: Palgrave Macmillan. https://doi.org/10.1007/978-3-319-64891-0

Pollifroni, M. (2005). Il bilancio di genere (gender sensitive budgeting) quale strumento di accountability proprio del modello della Public Sector Social Responsibility: un'analisi comparata tra prassi internazionale e nazionale", in AA.VV., Riferimenti storici e processi evolutivi dell'informativa di bilancio tra dottrina e prassi. Atti del VII Convegno Nazionale della Società Italiana di Storia della Ragioneria, Atri-Silvi (TE), 22-23 settembre 2005, (pp. 337-371). Roma, Italy: Rirea.

Pollifroni, M. (2008). Stakeholder Engagement Policies: searching for the positive performances by a Theoretical Model applied to the Italian Public Sector. Economia Aziendale Online, 1(2-3), 73-90.

Pulejo, L. (2011a). La gender equality nell'economia dell'azienda. Strategie e strumenti di mainstreaming di genere per lo sviluppo sostenibile. Milano, Italy: FrancoAngeli.

Pulejo, L. (2011b). Il profilo del genere nella programmazione delle aziende pubbliche territoriali. Management Control, 2, 59-83.

Quinn, S. (2016). Europe: A survey of gender budgeting efforts. Washington, DC: International Monetary Fund. https://doi.org/10.5089/9781475520088.001

Quinn, S. (2017). Gender budgeting in Europe: What can we learn from best practice? Administration, 65(3), 101-121. https://doi.org/10.1515/admin-2017-0026

Razavi, S. (2016). The 2030 Agenda: challenges of implementation to attain gender equality and women's rights. Gender \& Development, 24(1), 25-41. https://doi.org/10.1080/13552074.2016.1142229

Rubin, M. M., \& Bartle, J. R. (2005). Integrating gender into government budgets: A new perspective. Public Administration Review, 65(3), 259-272. https://doi.org/10.1111/j.1540-6210.2005.00452.x

Sharp, R., \& Broomhill, R. (2002). Budgeting for equality: The Australian experience. Feminist economics, 8(1), 25-47. https://doi.org/10.1080/1354500110110029

Siboni, B., Sangiorgi, D., Farneti, F., \& De Villiers, C. (2016). Gender (in) accounting: Insights, gaps and an agenda for future research. Meditari Accountancy Research, 24(2), 158-168. https://doi.org/10.1108/MEDAR-04-2016-0054

Sodani, P. R., \& Sharma, S. (2008). Gender responsive budgeting. Journal of Health Management, 10(2), 227-240. https://doi.org/10.1177/097206340801000205

Steccolini, I. (2019). New development: Gender (responsive) budgeting - a reflection on critical issues and future challenges. Public Money \& Management, 39(5), 379-383. https://doi.org/10.1080/09540962.2019.1578538

Stotsky, J. G. (2006). Gender Budgeting. Washington, DC: International Monetary Fund. https://doi.org/10.5089/9781451864922.001

Stotsky, J. G., Kolovich, M. L., \& Kebhaj, S. (2016). Sub-Saharan Africa: A Survey of gender budgeting efforts. Washington, DC: International Monetary Fund. https://doi.org/10.5089/9781475520033.001

Tommaso, S., Pastore, P., \& Andriolo, M. (2019). Strategic Governance and Gender Budgeting of Local Governments: Paths and Experiences in Italy. In International Conference on Gender Research (pp. 613-621). Academic Conferences International Limited. 
UN Women. (2019). Generation Equality. Realizing women's rights for an equal future. Retrieved from https://www.unwomen.org/-/media/headquarters/attachments/sections/library/publications/2019/generationequality-realizing-womens-rights-for-an-equal-future-en.pdf?la=en $\& v s=4330$

United Nations (UN). (2014). Gender Equality in Public Administration. New York: United Nations Development Programme, 2014. Retrieved from

https://www.undp.org/content/undp/en/home/librarypage/democratic-governance/public_administration/gep a.html

Vaismoradi, M., Turunen, H., \& Bondas, T. (2013). Content analysis and thematic analysis: Implications for conducting a qualitative descriptive study. Nursing \& Health Sciences, 15(3), 398-405. https://doi.org/10.1111/nhs.12048

Velte, P. (2017). Do women on board of directors have an impact on corporate governance quality and firm performance? A literature review. International Journal of Sustainable Strategic Management, 5(4), 302-346. https://doi.org/10.1504/IJSSM.2017.089125

Villagomez, E. (2004). Gender Responsive Budgets: issues, good practices and policy options. Geneva: UN, Economic Commission for Europe. London, England: Routledge.

\section{Copyrights}

Copyright for this article is retained by the author(s), with first publication rights granted to the journal.

This is an open-access article distributed under the terms and conditions of the Creative Commons Attribution license (http://creativecommons.org/licenses/by/4.0/). 